\title{
Traditional conservation and human-primate conflict in Ujungjaya Village Community, Ujung Kulon, Banten, Indonesia
}

\author{
SIDIK PERMANA ${ }^{1}$, RUHYAT PARTASASMITA ${ }^{1, \boldsymbol{v}}$, JOHAN ISKANDAR $^{1}$, ENENG NUNUZ ROHMATULLAYALY $^{1}$, \\ BUDIAWATI S. ISKANDAR ${ }^{2}$, NICHOLAS MALONE ${ }^{3}$ \\ ${ }^{1}$ Department of Biology, Faculty of Mathematics and Natural Sciences, Universitas Padjadjaran. Jl. Raya Bandung-Sumedang Km 21, Jatinangor \\ Sumedang 45363, West Java, Indonesia. Tel.: +62- 22-7797712, `email: ruhyat.partasasmita@unpad.ac.id; rp2010rikkyo@gmail.com \\ ${ }^{3}$ Department of Anthropology, Faculty of Social and Political Science, Universitas Padjadjaran. Kampus Jatingangor, Jl. Raya Bandung-Sumedang Km \\ 21, Jatinangor, Sumedang 45363, West Java, Indonesia \\ ${ }^{4}$ Anthropology, Faculty of Arts, University of Auckland. Social Sciences Building, 10 Symonds Street, Auckland 1010, New Zealand
}

Manuscript received: 24 November 2019. Revision accepted: 14 January 2020.

\begin{abstract}
Permana S, Partasasmita R, Iskandar J, Rohmatullayaly EN, Iskandar BS, Malone N. 2020. Traditional conservation and human-primate conflict in Ujungjaya Village Community, Ujung Kulon, Banten, Indonesia. Biodiversitas 21: 521-529. In the past, rural Sundanese people's interactions with wild animals, including nonhuman primates (hereafter 'primates'), is influenced by traditional ecological knowledge (TEK) with foundations in various myths and beliefs. Today, because of environmental changes, development of a market economy, cultural change, and the enhancement of agricultural technology, the beliefs and practices associated with TEK have eroded. We aim to describe the present perceptions of primates by the Sundanese people of Ujungjaya Village, Sumur Subdistrict, Ujung Kulon, Banten Province, and demonstrate how these myths and beliefs manifest in behavior towards primates. We use qualitative methods based on an ethnobiological approach to gain insight into people's perceptions of their natural surroundings. Our results show that the people of Ujungjaya still maintain deep perceptions that are manifested in stories, songs, poems, spells, and invocations that prohibit the killing of primates. However, on their own, these manifestations are insufficient to protect primates from harm as the penetration of market economies and the fragmentation of habitats create the conditions for increased human-primate conflict. Indeed, the people of Ujungjaya sometimes hunt and capture primates for consumption, trading, and medicinal use. As such, laws and regulations designed to promote conservation are insufficient without an understanding of the cultural and socio-economic aspects of people's lives.
\end{abstract}

Keywords: Ethnobiology, ethnoprimatology, human-primate conflict, primate myths, Sundanese, Ujung Kulon

\section{INTRODUCTION}

Sundanese rural people which located in West Java and Banten in their interactions with the wild animals that inhabit their lands, rely on cultural understandings of wild animals as evidenced by mental frameworks and local, linguistic constructs (Brosius et al. 1986; Partasasmita et al. 2016a, 2016b). For Sundanese people, traditional ecological knowledge (TEK) is handed down from generation to generation by cultural transmission, with ancestors imparting knowledge about relationships among living beings (including humans), and between beings and their environment (Berkes 1993; Alves and Souto 2015; Permana et al. 2018). An important aspect of TEK is an understanding of local species (including primate) richness and abundance. TEK, or local knowledge of species diversity, is not static, but is a dynamic system that is influenced by various factors, such as: the development of market economies, socio-cultural change, habitat fragmentation, and agricultural modernization (Cowlishaw and Dunbar 2000; Partasasmita et al. 2016a, 2016b; Permana et al. 2019). The development of a market economy and cultural change (e.g., the influence of urban lifestyles) impact rural areas, and may lead to behavioral changes among rural people.
TEK is also impacted by the alteration of landscapes. The transformation of forests into agricultural land and settlements causes not only the reduction of primary habitat, but also impacts people's relationship to nature and society (Wessing 1993). Additionally, the introduction of pesticides and inorganic fertilizers causes water pollution for wet rice fields, rivers, and fish ponds (Iskandar 2014; Iskandar 2015). All these factors, either directly or indirectly, can impact the health and persistence of primate populations, especially as some species extend their ranges to include anthropogenic landscapes. Despite these threats, primate diversity within the forests surrounding Ujungjaya Village is still high, based on field survey that have been conducted, recorded 5 primate species namely the silvery gibbon (Hylobates moloch), the ebony langur (Trachypithecus auratus), the crab-eating macaque (Macaca pascicularis), the grizzled langur (Presbytis comata), and Javan slow loris (Nycticebus javanicus). We investigate the possibility that this diversity is related to the maintenance of TEK.

The efficacy of myths and beliefs in relation to the management of natural resources and the protection of biodiversity is debated among anthropologists and conservationists. (Emieaboe et al. 2014; Berkes et al. 2000; Carlson and Maffi 2004). Myths and beliefs underpin a 
variety of behavioral interactions between humans and wild animals, including conflicts, taboos and forms of utilization (Johansson 2008; Nijman \& Nekaris 2015; Iskandar et al. 2016; Partasasmita et al. 2016a, 2016b). For example, rural Sundanese communities who inhabit the Cisokan watershed in West Java possess a shapeshifting myth where endemic primate species, including the silvery gibbon (Hylobates moloch) and the grizzled langur, or surili (Presbytis comata), can morph into a clouded leopard (Panthera pardus). Because of this, certain attitudes commonly held toward leopards were extended to the primates (Permana et al. 2019). The present article examines traditional conservation attitudes of Sundanese rural people inhabiting Ujungjaya Village, adjacent to Ujung Kulon National Park, Pandeglang District, Banten Province. Of special concern are instances where changes of perception towards primates may lead to conflicts between human and primates. Besides perceptions, this article also describes various factors influencing humanprimate conflicts.

\section{MATERIALS AND METHODS}

\section{Research location}

Research was conducted at Ujungjaya Village, Sumur Subdistrict, Pandeglang District, Banten Province (Figure 1). The distance from the administrative office of the Sumur Subdistrict is approximately $24 \mathrm{~km}$ and can be reached by public transportation in a small car (elf) or motorbike (ojek) which can take up to 2 hours. The road conditions are variable, and can be hazardous during the rainy season and subject to low visibility from intense, wind-churned dust during the dry season. The distance from the city of Serang, the capital city of Banten Province, is approximately $140 \mathrm{~km}$ and can be reached by elf within 6 hours.

Ujungjaya has total area of approximately 864 ha, inhabited by 4,320 people with population density of approximately about 45 people $/ \mathrm{km}^{2}$. Topographically, this village is hilly and very close to the sea, with an altitude of $8 \mathrm{~m}$ above sea level and an average air temperature of $27-$ $32{ }^{\circ} \mathrm{C}$. On the basis of filed survey that have been conducted, Ujungjaya people recognize various types of ecosystem, including sea (laut), coastal (basisir), river (walungan), estuary (muara), mixed-garden (kebon), wet rice fields (sawah), homegarden (pakarangan), and forest (leuweung). Administratively, Ujungjaya Village territory is bordered to the north by Taman Jaya Village, to the south by Ujung Kulon National Park (UKNP), to the east by the Mt. Honje Ranges (UKNP), and to the west by the Sunda Strait.

The most common livelihood of Ujungjaya people is recorded as farmers and fisheries. Those two kinds of livelihood are affected by season. When rain season is coming, most of local people working as farmers in wetrice field and mixed-garden. Meanwhile, in dry season most of local people collecting forest products in the forest and go to the sea as fisheries. In addition, they also have off-farm and non-fisheries activities such livestock namely fish ponds, sheep, and buffalo. Other occupations, such as running small businesses in shop (warung), tourist guide, civil service employee, teacher, and opening motorbike repair shop (bengkel). Similar to other Sundanenese rural people in West Java and Banten Province, the main food source of Ujungjaya people is rice. Then, religion of Ujungjaya people is Islam, exactly can categorized as traditional Islam.

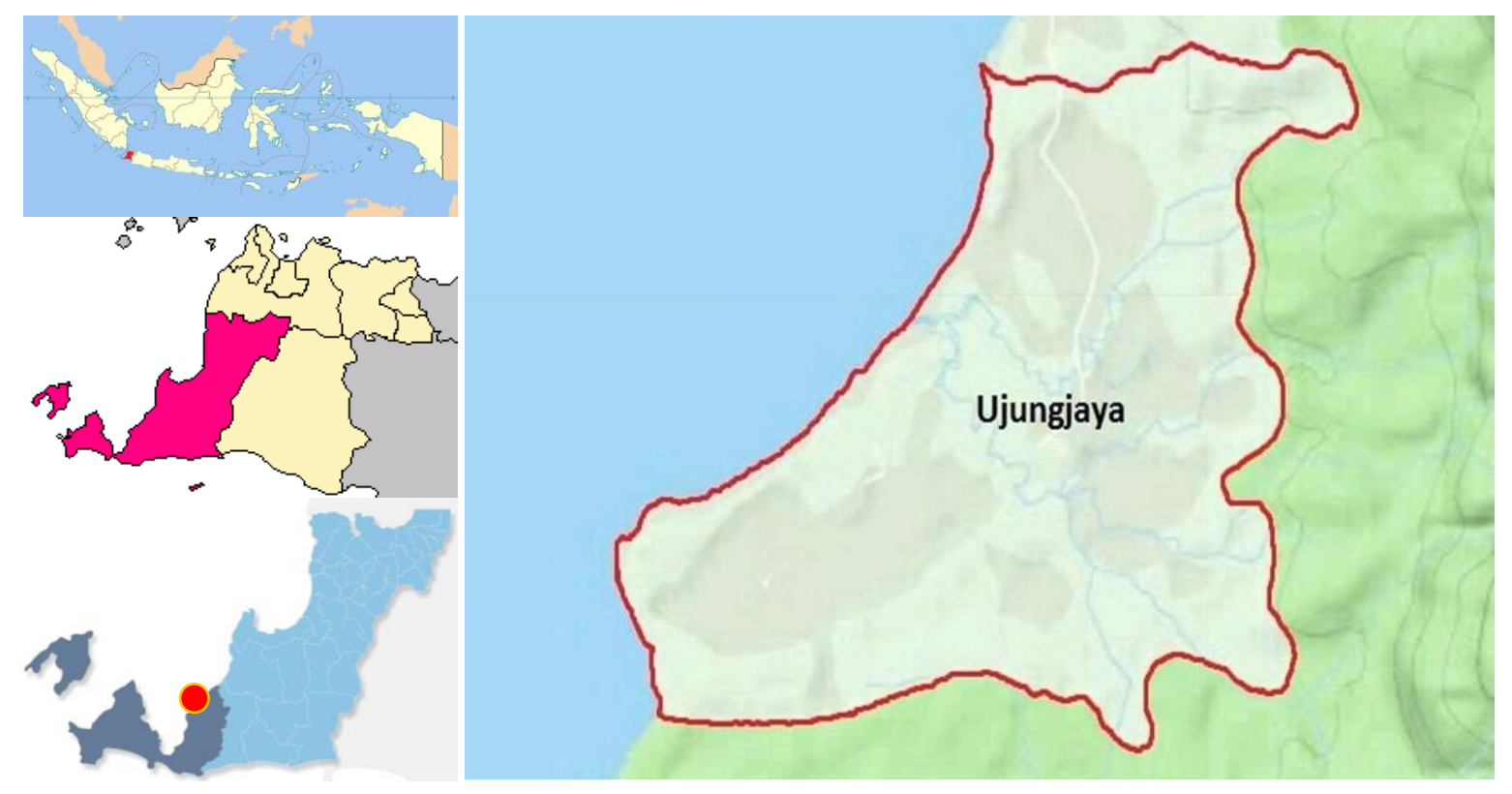

Figure 1. Location of Ujungjaya Village, Sumur Sub-district, Pandeglang District, Banten Province, Indonesia 


\section{Data collection}

This research used a qualitative method based on an ethnobiological approach (Iskandar 2018; Berlin 1992; Johnson 1974; Hunn and Brown 2011). Data were collected using three techniques including ethology, participant-observation, and semi-structured interviews. Animal census techniques were conducted by transect walks to confirm the presence of primate species in the forest surrounding Ujungjaya Village, including the sacred forest of leuweung karamat Cimahi, the Cikacang waterfall, and the Cikawung estuary. Participantobservation with a variety of local people was conducted with a variety of forest users, including with hunters as they prepared and set traditional traps and weapons, and with mixed-garden farmers. Additionally, researchers, together with informants, participated in daily activities including social gatherings, explorations of the forest and mixed-gardens, and other aspects of daily life within the hamlets. Semi-structured interviews with 17 informants were selected purposively to sample across various categories of age and gender. Some of the informants involved in this research were the village head of Ujungjaya and his staff, officers of Ujung Kulon National Park, healers (dukun), peasants (petani), hamlet leaders (kokolot), animal hunters (pemburu binatang), collectors of forest products (tukang ngalasan) including honey pickers, collectors of firewood, and gatherers of plants. Semistructured interviews were conducted with competent informants who possessed knowledge of primate diversity, habitat and population parameters, human-primate interaction, hunting techniques, and myths and/or beliefs related to the primates (Iskandar 2018).

\section{Analysis of data}

Data were cross-checked through a process of triangulation, summarization, and categorization. Data were placed into categories to find patterns and themes relevant to the research problem (Newing et al. 2011; Iskandar 2018). The assembled data were interpreted based on two perspectives: the internal perspective of informants (emic view) and an objective, scientific perspective (etic view) (Iskandar 2018).

\section{RESULTS AND DISCUSSION}

\section{Perceptions of primates by the people of Ujungjaya}

In the past, rural people of Java, and more generally throughout Southeast Asia, perceived the forest (leuweung) as a dangerous and unsafe place inhabited by many spirits, including those of ancestors. Those spirits of place were believed to be embodied by wild animals (Wessing 1995; Wessing 1999). In addition to believing that spirits can possess and inhabit the body of wild animals, they also believed that various wild animals can shapeshift into humans, or the reverse-that wild animals can morph into humans (Wessing 1995; Rye 2000; Iskandar 2018; Permana et al. 2019). Like other groups in rural Java, Ujungjaya people also believe that all wild animals inhabiting the forest were known as invisible animals (sato nyiluman), or animals possessed by spirits. Because wild animals have a strong sense of smell and sight, they can see humans. Similarly, domesticated animals can be invisible animals if they enter the forest.

Our study revealed that Ujungjaya people held beliefs directly related to the local primate community, such as the silvery gibbon of Java (Hylobates moloch), the crab-eating macaque (Macaca fascicularis), the ebony langur (Trachypithecus auratus), and the Javan slow loris (Nycticebus javanicus). Additionally, an important placebased myth is held of the sacred (karamat) Cimahi forest that represents a core component of the primates' habitat.

\section{Myth of the silvery gibbon}

Ujungjaya people, and commonly also people from the surrounding UKNP, believe that the silvery gibbon, called kuweung in local language, originated when a pair of children were banished to the forest (leuweung) by their uncle. Because silvery gibbons come from humans, they were not to be disturbed or harmed. An elder participant described the story in detail. Once upon a time, a brother and sister (orphans) were left to die by their parents. But before their parents died, the father commanded of his older brother to take care of his children and property, and to give the property to the children when they grew older"ka ieu anak kula titip sabab kula gering bisi kula teu umurna, ieu anak kula urus jeung pangaboga kula rawat ku kaka, engké anak kula gedé bikeun'. The older brother was a rapacious and cunning character, and wanted to dominate the property that was left for his younger brother. Instead of caring for the children, he banished his nephew and niece to the forest. He built a treehouse (ranggon) in the forest. The uncle commanded his nephew and niece to go up into the treehouse, and not to come down to the ground. The uncle set about cooking rice (liwet) intended for the nephew and niece in a bamboo grove. Secretly, the uncle left the forest. After three months had passed, the nephew and niece called their uncle, "uwa come back to saung (small house) because the rice has been burnt" (in Sundanese language, uwa is a term for the older brother of a father or mother). After that, the children's bodies were transformed: from pores of skin grew long hair, and they ate anything fruit growing in the trees.

Vocalizations of silvery gibbons are usually heard in the mornings. For the people of Ujungjaya, the gibbons' songs and calls are valued, and provide comfort and peacefulness that enriches daily activity. Additionally, people also perceive gibbon vocalizations as an indicator of seasonal change. It is said that if the gibbon continuously calls (nyawara), both in the morning and evening, a long, dry season can be predicted-the gibbon calls representing a request for rain to soon fall again. On the contrary, if a solitary silvery gibbon (kuweung nunggal) calls continuously in the morning (participant gestures toward the forest of Jaga Besar, south part of the Mt Honje ranges), it can be a sign that soon rain will fall. In other words, seasonal transitions-from dry season to rainy season-are signaled by the vocalizations of silvery gibbons. For some, the gibbon vocalization is also interpreted as an indicator of death. People believe that continuous gibbon 
calls, from daylight tonight, are a sign that will be a death soon, near to their residence.

\section{Myths and tales of the crab-eating macaque}

In our research, participants also narrated a local myth about how a shapeshifting human became a crab-eating macaque. According to locals, in the past there was a student of a traditional Islamic boarding school (santri) with deep knowledge of Islam. The student was commanded by the teacher (kiyai) to weed (ngarambét), a wet rice field. The santri went to the wet rice field and carried out the teacher's command, but his hunger could not be ignored. The student ate from the wet rice field. Meanwhile, the wife of the teacher (nyai) went to the rice field and brought some food for him. When Nyai found out about the student's meal of rice, nyai became angry and said to the student "monyét doang dia", or you are no more than a monkey. The meaning of these words is to liken the student's behavior to that of a monkey. Subsequently, the student transformed into the crab-eating macaque.

Additionally, there is the tale of the monkey and the tortoise (sakadang monyét jeung sakadang kuya), Sakadang is a Sundanese term that refers to a family or group of animals. Once upon a time, there was a long-tail macaque and a tortoise, and each of them had a mixedgarden (kebon). They spoke to each other and both had a desire to plant banana trees in their kebon. The long-tail macaque selected banana male buds (jantung) to use as seeds. Meanwhile, the tortoise selected banana shoots (sénggéh) for the seeds. After a few months, each of them observed their progress. After seven months passed, the tortoise's banana trees began to bear fruit. The banana trees owned by the long-tail macaque also bore fruit, but they were all rotten. Seeing the success of the tortoise, the monkey became angry. However, because the tortoise cannot climb up into the banana tree, the tortoise needed help from the long-tail macaque in order to pick banana fruits. The malicious monkey tricked to the tortoise. The long-tail macaque climbed-up into the banana tree and ate all of the bananas. Meanwhile, the tortoise, positioned under the banana tree, only got the discarded remains.

In the context of cultural norms among the people of Ujungjaya, these myths and tales reinforce the association of 'bad' characteristics, such as naughtiness, maliciousness, rapaciousness and untrustworthiness, with the nature of monkeys. Parents usually tell their children to not eat in the trees (ulah barangdahar di luhur siga urang leuweung baé), because this imitates monkey behavior. Parents are also quick to admonish disrespectful or disharmonious behavior by telling their children "kawas monyét doang dia"-or you are behaving like a monkey by exhibiting such characteristics. Based on these myths and tale of the crabeating macaque, for Ujungjaya people crab-eating macaque is perceived negatively. But for Bali people, crab-eating macaque is sacred, because narrated in Hindu books and the presence at temple during production of ritual associated with sacredness of temple in Bali (Peterson and Riley. 2017). Contrary, crab-eating macaque for Bali transmigrant in South Sulawesi is not sacred, because rarely visit transmigrant temple or not involved in ritual productions of sacredness, and life in the forest (Peterson et al. 2015).

\section{Myths of the ebony langur}

Ujungjaya people perceive ebony langurs (Trachypithecus auratus) as incarnations of a deity, namely Lutung Kasarung. This god has been sent by his father (Guruminda) and mother (Sanghyang Rétri), down to earth. Shaped into a black monkey, Lutung Kasarung is tasked with protecting Nyi Pohaci in the middle of sugar palm tree. Lutung Kasarung has a duty to guard the top of the sugar palm tree (birus). To help Lutung Kasarung, Guruminda sent Prabu Perunggu to assist by protecting the root of the sugar palm tree. People of Ujungjaya believed that part of the root was immortal-the root will grow again and again because of the protection granted by Prabu Perunggu. Besides that, people believe that they cannot pick shoots carelessly from the sugar palm tree, because Nyi Pohaci is there, in the middle of tree. If they wish to pick shoots from the tree, they must first ask permission from Nyi Pohaci.

Prior to coming down to earth, Lutung Kasarung, with his handsome face and dashing movements, enjoyed a fine life in the magnificent kingdom. In contrast, nomadic life in the forest would be filled with misery and poor conditions because he lacks a permanent residence. Kasarung, in the local language, means to not have a home. His younger sister, called Naga Lenggang, wanted to follow her brother and live in the forest, but he protested because life in the forest is full of dangerous things including spirits, bandits, and wild animals that can attack and kill at any time. The story of Lutung Kasarung wandering in the forest, and his sister who wanted to follow, is described in a poem which usually accompanies various traditional ceremonies and purification rituals, such as mipit paré (after rice-cutting); kendang pencak (martial arts performance); ngaruwat imah (house purification); and ngaruwat bumi (land purification).

Kaka ilu, kaka ilu, kaka

Adi ulah, adi ulah

Loba cucuk, salak hideung

Loba jurig nyiliwuri

Loba kélong, néwo-néwo

Loba garong, tolong tonghok

Kaka samping beureum pitiungeun

Samping hideung pitilameun

Boéhna keur pirurubeun.......

It may be translated as follow;

Big brother I want to follow you, big brother, I want to follow you, big brother

Brother, you are not allowed, you are not allowed

A lot of thorny bushes of zalacca

A lot of evil people in disguise

A lot of bad people disguise and screw up

Lots of robbers come (tolong tohok)

Big brother [this is] red cloth to be female hood

Its shroud for wrapping corpse.......

Lutung Kasarung not only encapsulates a nomadic life in the dangerous forest, but is also believed to have the power to cure short-sightedness. The procedure begins by 
placing a glass of water in front of a traditional singer (sindén) who then sings songs referencing Lutung Kasarung. After the singer finishes the song, the water is consumed. Lutung Kasarung's song also has the ability to cure bites of the rice snake (Hypsiscopus plumbea). During the singing of the song, one places their hands on the part of the leg that was bitten by a rice snake. In addition to the songs and stories, Lutung Kasarung also refers to a spell (rajah or jangjawokan) which is often used in agriculture, especially planting activities. Local people also believe that Nyi Pohaci was the goddess of fertility who guards and protects all kinds of plants in the world, including rice. This spell also describes cosmos-ecological connections between Lutung Kasarung as an animal, and Nyi Pohaci as a plant-a natural force which is manifested in the gods.

\section{Allohumma umur dunya}

Salamet kawula di dunya

Berkatulloh Nyimas Pohaci nu ngajaga katanian

Naga herang naga lenggang, naga pangawasa Alloh

Turun ti Sanghyang Prabu-

Ditampa ku Guruminda digjaya ku para déwata

Prabu Lutung Kasarung, Nyimas Pohaci, Dangdayangan Trisnawati

Pangambilangkeun aing

Tinu samata, tinu dua mata-

Tinu sacangci, tinu dua cangci

Tinu saranggeuy, tinu dua ranggeuy

Tinu sagedeng, tinu sapuluh gédéng

Lobana saratus, reana salawé

Ditetepkeun ku aing di bumi manik

Mayadenta di bukit nagara pageuh

Sanghyang Gunung Kancana rit perit singadati

Kagungan Gusti Cirebon

Leuit teu kena ku ipis

Nu diwadahan teu keuna ku euweuh

Pohaci sumping jumanten

Berkat lailahaillalloh muhammadurosululloh

It may be translated as follow:

Allohuma world age

I survive in the world

Your gift Rice goddess-Nyi Pohaci-who look after agriculture

The big dragon due to God power

Inherited from Sanghyang Prabu

Received by Guruminda and girded by God

Prabu Lutung Kasarung, Nyimas Pohaci, Dangdayangan

Please help to count for me

From one seed become two seeds of rice

From a sprig of rice into two rice stalks

From a sprig into two rice stalks

From one rice bundle into ten rice bundles

One hundred lots, at least twenty five

Placed by me at the earth (Bumi Manik)

In order to be sturdy strong

Sanghyang Gunung Kancana rit perit singadati

Belongs to the sultan Cirebon

Rice barn never tobe thin

What's saved is never lost

Welcome for rice Goddes (Pohaci

Blessing from God and Muhammad is the messenger of God

Ancestors have given a directive to descendants not to disturb or kill the ebony langur. Because of this belief, the people of Ujungjaya are prohibited to kill ebony langurs. It is said that if they are disturbed, it can trigger a disaster.
Related with breaking this prohibition, one of informal leaders near the Cikawung estuary told us that one day a young man tried to shoot an ebony langur at the side of the estuary. The young man intended for this animal to be sold to an urban buyer. Even though he was unsuccessful in his attempt, he consequently fell ill with stomach pains.

In addition to appearing in myths, songs, spells, and prohibitions, ebony langurs also feature as inspiration for humorous rhymes or jokes. The humorous rhymes related to ebony langurs describe people who have toothaches (nyeri huntu) that must bite sweet potato (mantang) in the forest while looking (neuleu) for an ebony langur (pamatang).

Ka gunung ka Ciarileu

Neuleu lutung di pamatang

Umur sagedé kieu

Nyeri huntu, ngégél mantang

It may be translated as follow:

Go to mountain to Ciarileu

To see the ebony langur at dyke

Age to this size

Toothache due to biting on sweet potato

\section{Myth of the crab-eating macaque, the ebony langur, and the leopard}

According to informants, monyét (crab-eating macaque) and lutung (ebony langur) are primates often preyed upon by leopards. In contrast, owa (silvery gibbons) and surili (grizzled langur) are rarely preyed upon by leopards. Monyét, mainly the immatures, are also preyed upon by python and estuarine crocodiles. Why is it that the monkey and langur are often preyed upon by leopards? Local people believe that the lutung and monyét have made an agreement to offer a sacrifice (puraga) to the leopard. Because of those agreements, one lutung is taken as an offering to the leopard every month. For the monyét, one individual is taken by a leopard every year. Monyét and lutung will become a victim if they were to lose a fight with a conspecific and had fallen down from the tree-, they would become leopard food. One time, a lutung (ebony langur) who has become puraga had a large body size and two-headed mischief (kukulinciran)-because of this he was not recognized by his group and was exiled to a life of solitude. The recorded prey choice of the leopard legitimizes these myths (Raharyono and Paripurno 2001; Permana et al. 2019).

\section{Myths of the Javan slow loris}

The people of Ujungjaya believed that the kukang, or Javan slow loris (Nycticebus javanicus), is sometimes called muka Brahma/geni, an animal who has frightening character (panas). As such, people do not disturb the muka, or else they risk triggering a disaster. A location where muka Brahma was exploited or killed could cause all species of plants to die. If in this place people built a settlement, the inhabitants would not be comfortable. Instead, they would face chronic stress and disease. Therefore, those places are not suitable for inhabitation or 
growing crops. Because, muka Brahma has frightening characteristic, all parts of their body, including fur and blood, can be used to harm other people. Because of these beliefs, one hamlet (Pasir), with a total area approximately $100 \mathrm{~m}^{2}$, was abandoned by the inhabitants because people there purposefully buried a muka Brahma. Prior to abandonment, many people were getting diseases and dying. Now, that hamlet is only occupied by four families. Similar beliefs associated with the Javan slow loris occurs in other rural Sundanese communities in West Java (Nijman and Nekaris 2004; Permana et al. 2019).

\section{Sacred burying ground}

Local people recognize the area of makam karamat (sacred burying ground) Cimahi as one of the healthiest examples of primate habitat in Ujung Kulon National Park. Ecologically, vegetation structure of makam karamat Cimahi was dominated by plants from the genus Ficus. Makam karamat Cimahi is favorable habitat for primates, including owa (silvery gibbon), lutung (ebony langur), and monyét (crab-eating macaque) because of the abundance and richness of dietary items. In the past, before many people began to make makam karamat Cimahi a location of frequent pilgrimage, this place was an untouched remnant (dungus) of dense, closed-canopy forest. The people of Ujungjaya believed if either injured wild animals (e.g., a buffalo shot by hunters), or sick people visited this place, they would recover because of the magical forces in this area. Today at makam karamat Cimahi there are five graves of saints, namely: Uyut or Syaikh Santika, Syaikh Dahlan, Uyut Nuralam, Uyut Marga, and Uyut Bidadari. Local people and pilgrims are prohibited to disturb or hunt primates, who are considered as the guardians of the graves. Failure to follow this prohibition would invite disaster and prevent their wishes from being granted. Pilgrims visiting makam karamat Cimahi are aware of the primates' presence, and often observe the animals moving and feeding in the canopy above. Primates do not disturb the pilgrims' religious practices. Although more research is required, the interactions between pilgrims and primates at makam karamat Cimahi may be broadly similar to the beliefs and practices associated with the Balinese temple macaques (e.g., at Padangtegal, Ubud, Bali) (Wheatly 1999; Fuentes 2010; Schillaci et al. 2010). At Padangtegal, the interactions of local people, tourists, and macaques, although nuanced and varied, are for the most part defined by a co-existence underscored by tolerance. Whether from the presence of tourists (Padangtegal) or pilgrims (makam karamat Cimahi), the complex emergence of a multispecies niche, with manifestations in both cultural expression and economic benefits, is of interest to anthropologists and conservationists.

\section{Human-primate conflicts}

Because of their proximity to Ujung Kulon National Park, the people of Ujungjaya interact with the forest (leuweung) and its inhabitants on a daily basis. Frequently, they meet primates when collecting forest products (ngalasan) and when hunting animals. Nowadays, people not only meet primates in the forest, far from settlements or hamlets, but often encounter them in mixed-garden and wet-rice fields near the forest edges. Local people often find macaques and ebony langurs eating crops in mixedgarden and wet-rice fields. Therefore, some informants now categorize these two species of primates as pests. For example, ebony langurs often disturb certain annual crops such as mango, papaya, banana, and chili leaf. However, ebony langur's behavior is not 'naughty' like the macaque, which disturbs almost all crop varieties. If ebony langur is known by local people to be eating fruit from mango and banana trees, people work to expel them. This is different from macaques, who come in large groups of between 2050 members to eat all crop varieties within the mixedgardens. Meanwhile, the silvery gibbon, surili, and Javan slow loris were not categorized as pests by any informants.

To handle the crop-foraging disturbances of macaques and langurs, based on participant-observation and semistructured interviews is recorded that local people used several techniques, including directly approaching the animals while screaming, throwing stones, or attempting to hit the monkeys with a wooden stick. Also, farmers build and occupy a small lodge (saung) for monitoring purposes, and make scarecrows (bebegig) from straw and clothes (tangkawing) that function to frighten monkeys and other wild animals such as wild boar and birds. Also, farmers deploy a noise-maker that is fabricated from used cans and is set-up in the wet-rice field. In local language, this is called kolécér, and the noise will be created as the wind blows. Also, frightening animals with cayut, a kind of helmet made from woven coconut leaves, is worn on the head when chasing monkeys out of a garden. Afterward, the cayut is positioned prominently at side of the mixedgarden, with the hope being that monkeys will assume that the person who chased them away is still guarding the crops. Sometimes, farmers shoot macaques and ebony langurs using a slingshot (bandil), made from wood and rubber, and a small stone as a projectile. In addition to bandil, local people sometimes used air rifles and traditional firearm (bedil locok) to shoot at monkeys and ebony langurs.

Local people have special techniques to handle monkey disturbance. They used various traditional traps, including picepet, karangkéng, jerat, kancung, porog, and tako. Picepet is a trap made from bamboo that measures approximately four meters in length. For making one picepet (pinch trap), the amount of bamboo needed is about four bamboo trees, and other supplementary materials such as snake fruit thorn. The trap is baited with fruit. Monkeys captured by a picepet trap will usually die as their waist or head will become severely 'pinched' in the thorns with considerable force.

Karangkéng is a bamboo trap with a cube-like form with an approximate height of 1.8 meters, a width between 1.5-2.0 meters, and a length of approximately 1.5-2.0 meters. The metal entrance door measures approximately 0.5 meter, and is suspended by rope. Bait in the form of jackfruit or banana is placed inside the karangkéng, and is commonly set in the evening. When monkeys enter the karangkéng, the entrance door will automatically close. Sometimes this can trap multiple monkeys. 

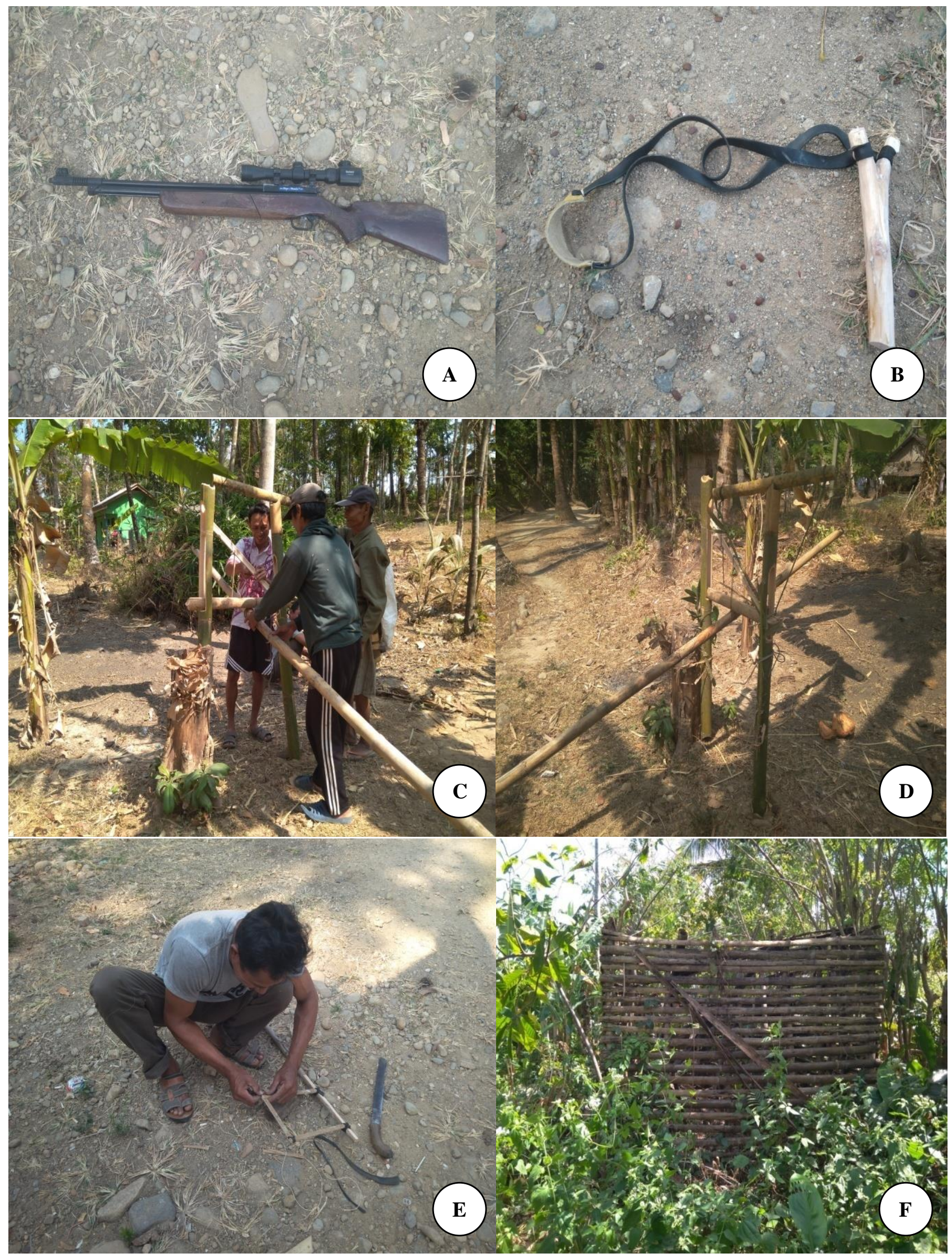

Figure 3. A. Air rifle used to shoot wild animals, including primates; B. Bandil is a traditional weapon that used to expel and shoot monkeys; C. Man making a picepet trap; D. picepet trap ready to use; E. A man making kancung trap; and F. An out-of-use and overgrown Karangkéng trap. 
Jerat is a trap that is similar to a fishing rod. The hanging jerat is made from bamboo and typically set during the day. In addition to monkeys, jerat are also used to catch Javan mouse-deer (peucang), wild chicken, wild cat, leopard, wild boar, and other wild animals. Kancung is a trap made from bamboo and placed on tree branches that are often used by monkeys. The kancung trap is usually installed in the evening. Besides monkeys, other wild animal species can be caught using this trap such as squirrels (buut), including the black giant squirrel or jaralang (Ratufa bicolor). Porog is a trap similar to a plaited rattan fish trap (bubu). Made from netting or ropes, when a monkey enters this trap, it cannot escape. Different from other types of trap, porog can be carried anywhere and positioned within trees that are frequently visited by monkeys.

Another technique used to handle monkey disturbances is a practice called the widaah ceremony. This ritual is believed to eliminate monkey pests by magical force. An essential element used in the widaah ritual is the head of a turtle (kuya leuleus) or tortoise (kuya batu). However, according to one informant, the head of the turtle is superior as it possesses a powerful force to eliminate monkeys. In this procedure, the head of the slaughtered turtle is buried in a (kebon) that has been frequently raided by monkeys. After burying the head of the turtle, reciting hadoroh prayers addressed to Nabi Khidir, bismilah sahadat and shalawat up to seven times should result in the elimination of the monkey pest problem. Generally, monkeys that are caught by local people will be released, killed, consumed, kept as a pet, or used in traditional medicine. Local people have been known to consume monkey meat and is said to have a delicious taste. Grilled ( disaté) primate flesh is also used in the treatment of skin diseases such as eczema or dermatitis. It is thought that children's intelligence can be improved by consuming cooked and seasoned (direndang) primate brains. Finally, the bile (hamperu) of the surili (grizzled langur) is used as a medicine for hair growth and fertility.

As mentioned earlier, macaques and ebony langurs are categorized as pests that disturb various crops within the mixed-garden and also the wet-rice paddies. Despite the fact that silvery gibbons, surili, and Javan slow loris are not considered to be pests, they are caught for selling to get money, primarily by the younger generation. In other words, the prohibitions that are embedded within myths and beliefs are now commonly violated. Several traditional traps, such as picepet, jerat, porog, and tako, used primarily to catch macaques and langurs, are also used by local people to catch silvery gibbons and surili. The Javan slow loris, it is said, can be caught directly by hand.

In summary, the ebony langur and crab-eating macaque have come into conflict with people because of agricultural expansion and intensification. Additionally, the coastal forest ecosystem is changing due to settlement patterns, shrimp farming, and sand mining operations. For example, around the hamlet of Tanjung Lame, the coastal forest, originally the habitat of ebony langurs and crab-eating macaques, has been transformed by a shrimp farming operation that includes a tourist lodge development of 42 units. With this operation and its related infrastructure, approximately 50 hectares of forest were transformed. Meanwhile, at the Cikawung estuary, which also is habitat for langurs and macaques, as well as other wild animals such as the estuarine crocodile, a sand mining operation threatens to erode this sensitive ecosystem. Therefore, primate habitat is in decline. Such declines can also lead to diminished carrying capacity and further instability. Such conditions, both directly and indirectly, threaten the existence of the primate species in this area (Cowlishaw and Dunbar 2000; Sampaio et al. 2016). Likewise, hunting and/or capturing primates to a point of local extinction will have further impacts on the regeneration of forests as primates play a major role as seed dispersers (Chapman and Onderdonk 1998). Given the importance of primates to this sensitive natural area, and the complexities of the present-day pressures faced by both wildlife and the local human population, a multifaceted approach to conservation will be required. Laws and regulations will not be sufficient without an understanding of socio-cultural dynamics and historical relationships between people, the forest, and its inhabitants.

\section{ACKNOWLEDGEMENTS}

This research was granted permission by RISTEK No. License 190/E5/E5.4/SIP/2019. We would like to thank you very much to the village chief and their staff, for providing local permission to conduct research in Ujungjaya Village, Sumur Subdistrict, Pandeglang District, Banten Province. We are also would to thank the officers of Ujung Kulon National Park, especially resort of Taman Jaya, for providing permission and research assistance. We would to like thank very much to the informants in Ujungjaya Village which have been given information when we were conducting research. Thank you to the ALG collaboration research program Prof. Johan Iskandar (Padjadjaran University) and Dr. Nicholas Malone (Auckland University), with the topics "Ethnobiology for Public Welfare" and "Site of Significance (Ujung Kulon National Park): Tourism at the Human and Nonhuman Primate Interface". This article is supported by Academic Leadership Grant (ALG) of Prof. Johan Iskandar, with the topic "Ethnobiology for the People Welfare to support Sustainable Development". Additionally, we also would like to thank the head of Biology Department, Padjadjaran University, for supporting our published findings, and for providing permission to conduct our fieldwork research.

\section{REFERENCES}

Alikodra HS. 1990. Wildlife management volume I. Ministry of Education and Culture, Directorate General of Higher Education, Inter-University Center for Life Sciences. IPB, Bogor. [Indonesian]

Alves RRN, Souto MS. 2015. Ethnozoology: a brief introduction. Ethnobiol Conserv 4 (1): DOI: 10.15451/ec2015-1-4.1-1-13.

Hunn ES. 2011. Ethnozoology. in Anderson EN, Pearsall DM, Hunn ES, Turner NJ (eds) Ethnobiology. John Willey \& Sons, New Jersey. 
Berkes F. 1993. Traditional ecological knowledge in perspective. In Inglis JT. (ed) Traditional ecological knowledge: concept and cases. International Program on Traditional Ecological Knowledge and International Research Center, Canadia.

Berkes F, Colding J, Folke C. 2000. Rediscovery of traditional ecological knowledge as adaptive management. Ecol Appl 10: 1251-1262.

Bismark M. 2009. Bekantan conservation biology (Nasalis larvatus). Center for Forest Research and Development and Nature Conservation, Bogor. [Indonesian]

Brosius JP, Lovelace GW, Marten GG. 1986. Ethnoecology: an approach to understanding traditional agricultural knowledge. in Marten GG (ed) Traditional agriculture in Southeast Asia: human ecology perspective. Westview Press, Boulder, Colorado.

Carlson TJS, Maffi L. 2004. Introduction: ethnobotany and conservation of biocultural biodiversity. In: Carlson TJS, Maffi L. (eds) Ethnobiology and conservation of biocultural diversity. New York: New York Botanical Garden. Chapman CA, Onderdonk, DA 1998. Forests without primates: primate/plant codependency. Amer J Primatol 45 (1): 127-141.

Cowlishaw G, Dunbar R. 2000. Primate Conservation Biology. University of Chicago Press, IL, USA

Djuwantoko, Rossanda T. 1996. Ecological behavior of Javanese gibbons in Pakenjeng natural forests, KPH, Garut, West Java. Buletin Fakultas Kehutanan Universitas Gadjah Mada No. 29/1996. UGM, Yogyakarta. [Indonesian]

Emieaboe PA, Ahorsu EK, Gbogbo F. 2014. Myths, taboos and biodiversity conservation: the case of hunters in rural communities in Ghana. Ecol Environ Conserv 20 (3): 879-886.

Fuentes A. 2010. Natural cultural encounters in Bali: Monkeys, temples, tourists, and ethnoprimatology. Cultural Anthropol 25 (4): 600-624.

Fuentes A. 2012. Ethnoprimatology and the anthropology of the humanprimate Interface. Ann Rev Anthropol 41: 101-117.

Hunn ES, Brown CH. 2011. Linguistic ethnobiology. in Anderson EN, Pearsall DM, Hunn ES, Turner NJ (eds.). Ethnobiology. John Willey \& Sons, New Jersey.

Iskandar J. 2014. Human and environments with various changes. Graha Ilmu, Yogyakarta. [Indonesian]

Iskandar J. 2015. Animal diversity: ecological benefits for human beings. Yogyakarta: Graha Ilmu [Indonesian]

Iskandar J, Iskandar BS, Partasasmita R. 2016.The Local knowledge of the rural people on species, role, and hunting of birds: case study in Karangwangi village, Cidaun, West Java, Indonesia. Biodiversitas 17: 435-446.

Iskandar J. 2018. Ethnobiology, ethnoecology, and sustainable development. Plantasia, Yogyakarta. [Indonesian]

Johansson T. 2008. Beasts on Fields. Human-Wildlife Conflicts in Natural-Culture Borderlands. [Disertation] Departement of Geography, Faculty of Science, University of Helsinki, Finland.

Johnson A. 1974. Ethnoecology and planting practices in a swidden agricultural system. Amer Ethnol 1 (1): 87-101.

Karyawati AT. 2012. General overview of feeding behavior on primates. J Sci Res 15: 15110 .

Maida S, Sukandar P, Istiadi Y. 2016. Variation of Javan gibbon vocalization structure (Hylobates moloch Audebert, 1798) in the Petungkriyono Protection Forest, Pekalongan, Central Java. Bioma 12 (1): 40-49. [Indonesian]

Newing H, Eagle CM, Puri RK, Watson CW. 2011. Conducting Research in Conservation: Social Science Methods and Practice. Routledge, London.
Nijman V, Nekaris K. 2015. Traditions and trade in slow lorises in Sundanese communities in Southern Java, Indonesia. Endangered Species Res 25: 79-88.

Parathian HE, Maldonado AM. 2010. Human-nonhuman primate interactions among Tikina People: perceptions and local initiatives for resource management in Amayacu in the Columbian Amazon. Am J Primatol 72: 855-865.

Partasasmita R, Iskandar J, Malone N. 2016a. Karangwangi people (South Cianjur, West Java, Indonesia) Local Knowledge and wildlife conservation. Biodiversitas 17 (1): 154-161

Partasasmita R, Shanida SS, Iskandar J, Megantara EN, Husodo T, Malone N. 2016b. Human-Leopard Conflict in Girimukti Village, Sukabumi, Indonesia. Biodiversitas 17: 783-790

Peterson JV, Riley EP, Oka NP. 2015. Macaques and the ritual production of sacredness among Balinese transmigrants in South Sulawesi, Indonesia. Amer Anthropol 117 (1): 71-85.

Peterson JV, Riley EP. 2017. Sacred monkeys? An ethnographic perspective on macaque sacredness in Balinese Hinduism. In Dore KM, Riley EP, Fuentes A (eds.). Ethnoprimatology: a practical guide to research at the human-nonhuman primate interface. Cambridge University Press, Cambridge.

Permana S, Iskandar J, Parikesit. 2018. Local knowledge on rice variations (landraces) of the Naga Community, West Java, Indonesia. Asian J Ethnobio 1 (1): 1-8.

Permana S, Iskandar J, Parikesit, Husodo T, Megantara EN, Partasasmita R. 2019. Changes of ecological wisdom of Sundanese People on conservation of wild animals: A case study in Upper Cisokan Watershed, West Java, Indonesia. Biodiversitas 20: 1284-1293.

Raharyono D, Paripurno ET. 2001. Tiger Friend with Nature. The Gibbon Foundation, Jakarta.

Rye S. 2000. Wild pig, 'pig men', and transmigrant in the rain forest of Sumatra. In: Knight J. (ed). Natural Enemies: People-Wildlife Conflicts in Anthropological Perspective. Routledge, London.

Sampaio MB, Souto A, Schiel N. 2016. Ethnoprimatology. In: Albuquerque UP, Alves R. (eds.). Introduction to Ethnobiology. Springer Nature, Switzerland.

Schilaci MA, Engel GA, Fuentes A, Rompis A, Putra A, Wandia IN, Bailey JA, Brogdon BG and Jones-Engel L. 2010. The not-so-sacred monkeys of Bali: A radiographic study of human-primate commensalism. In: Indonesian Primates. Springer, New York.

Sponsel LE. 1997. The Human niche in Amazonia: explorations in ethnoprimatology. In Kinzey WG (ed.). New World Primates: Ecology, Evolution, and Behavior. Walter de Gruyter Inc., New York.

Toledo VM. 1992. Indigenous people and biodiversity. Institute of Ecology, National University of Mexico, Mexico.

Wheatley BP. 1999. The Sacred Monkeys of Bali. Waveland, Prospect Heights, NY.

Wessing R. 1993. A change in the forest: Myth and history in West Java. J Southeast Asian Stud 24 (1): 1-17.

Wessing R. 1995. The last tiger in East Java: symbolic continuity in ecological change. Asian Folklore Stud 54: 191-218.

Wessing R. 1999. The sacred grove: founders and the owners of forest of in West Java, Indonesia. In: Bahuchet S, Bley D, Pagezy $\mathrm{H}$, Vernazza-Licht H. (eds.). L'Homme et La Foret Tropicale. Chatenauneaf-de-Grasse. Editions de Bergier (Travaux de la Societe de Ecologia Humaine). [France] 